\title{
Formulation of pea milk fortified dahi incorporated with jamun seed extract
}

\author{
Shikha Pandhi and Amrita Poonia
}

Received: 05 July 2020 / Accepted: 08 December 2020 / Published online: 28 February 2021

(C) Indian Dairy Association (India) 2021

\begin{abstract}
Changing market trend have paved the way for development of value-added products fortified with plant-based constituents for supplementing their therapeutic potential. In sight of this, fortified dairy products have gained immense attention in recent times. The present study was undertaken with an aim to fortify animal-based nutrients with plant-based nutrients by developing a pea milk fortified $d a h i$ incorporated with jamun seed extract. A ratio of 5:1 (5 parts of water and 1 part of pea) for pea milk formulation and 3:2 (3 parts of pea milk and 2 parts of skim milk) for fortification of milk was used for dahi preparation. The developed product exhibit good per cent antioxidant activity of $80.1 \pm 8.84$ and total phenolic content of $98.33 \pm 15.56 \mathrm{mg}$ of gallic acid equivalent (GAE)/ml of dahi sample with an overall acceptability of 8.6 on 0 day followed by an overall acceptability score of 6.2 on $12^{\text {th }}$ day of storage which is the predicted shelf life of the product with successive decline in per cent antioxidant activity and total phenolic content beyond this period. Other parameters such as water holding capacity, viscosity and syneresis were found to be $60.35 \pm 1.34 \%, 38 \pm 0.2 \mathrm{cP}$ and $8.2 \pm 0.4$ $\mathrm{ml} / 100 \mathrm{~g}$, respectively. Physicochemical parameters and textural analysis was also performed. The final cost of product was estimated to be Rs.13 per cup (100g) which is quite comparable to the market dahi.
\end{abstract}

Keywords: Dahi, Fortified, Jamun seed extract, Pea milk

\footnotetext{
Department of Dairy Science and Food Technology, Institute of Agricultural Sciences, Banaras Hindu University, Varanasi-221 005, Uttar Pradesh, India

Amrita Poonia $(\square)$

Department of Dairy Science and Food Technology, Institute of Agricultural Sciences, Banaras Hindu University, Varanasi-221005, Uttar Pradesh, India

Phone:9644305305

Email: dramritapoonia@gmail.com
}

\section{Introduction}

The conception of novel idea of functional food has paved the demand for development of food products that not only provides basic nutrition, but also affirms goof health and longevity (Fazila et al. 2018). Dahi is a fermented product obtained after fermentation of milk by addition of starter culture to offer easily digestible nutrients with potential therapeutic effects (Sandhya et al. 2018). This has made dahi a preferred product to be explored from a functional food aspect. In view of this, the researchers are continuously investigating different functional ingredients for their potential beneficial effects such as probiotics, prebiotics, plant extracts etc (Fazila et al. 2018). Plant consists of an array of bioactive components known for their potential therapeutic and health-promoting effects (Naczk and Shahidi, 2006). The incorporation of these plant constituents known as "phytochemicals" in to various food products is a leaning trend in the current market. They have known to exhibit high antioxidant, anticarcinogenic, antimicrobial, anti-atherogenic, anti-inflammatory (Zimmer et al. 2012), antidiabetic and antihypertensive activities (Yadav et al. 2018). Incorporation of these phytochemicals into dairy products has received considerable attention in the food industry to improve both nutritional and functional value of the product.

Syzygium cumini (commonly known as "jamun") is a very large evergreen tropical tree belonging to the family Myrtaceae (Pandhi and Poonia, 2019). The presence of various phytoconstituents contributes to the anti-diabetic, antioxidant and/or antimicrobial activity. Jamun seed powder has been used for centuries as a natural form for balancing the healthy blood sugar level and is the most studied plant part. They are reported to contain jamboline, gallic acid, ellagic acid, corilagin, 3,6hexahydroxy diphenoylglucose, 4,6hexahydroxydiphenoylglucose, 1-galloylglucose, 3galloylglucose, quercetin, $\beta$-sitoterol (Baliga et al. 2011). The glycoside, named Jamboline is mainly responsible for maintenance of glucose levels as in the normal limits (Desai et al. 2019). Further, the emerging demand for alternative protein sources apart from animal milk have necessitates the exploration of plant based protein sources. Soybean milk has been effectively explored for development of various commercial products due to 
its distinct characteristics such as ability to bind calcium. In sight of this, the other important crop that is emerging is- yellow peas. Pea is among the oldest food legume crops that are recognized as an inexpensive and readily available source of protein, complex carbohydrates (especially starch), vitamins and minerals. The higher nutrient density of dry peas makes them a valuable food commodity that is capable of fulfilling the dietary requirements of millions of undernourished individuals worldwide (FAOSTAT, 2011). Dry peas possess many functional and nutritional properties and are generally consumed as dhal, stews, snacks, vegetables and flour. Various nutrients present in dry peas may help in lowering the risk of heart diseases, stroke, and various cancers, while enhancing quality of life by helping manage weight. The soluble fiber in dry peas and low glycemic index may help stabilize blood sugar levels, which is especially important for people with diabetes (Parihar et al. 2016). Pea's essential proteins can be extracted as pea milk using different method and can be used to fortify animal milk in different ratios as a "new raw material" (Denkova et al. 2013).

In view of the increasing consumer interest towards improving their overall health and reducing the risk of specific disorders provide great opportunities for expanding dairy based products to provide benefits beyond their traditional nutritional value. Present study aims at developing a pea milk fortified dahi incorporated with jamun seed extract for combining the benefits of peas with milk.

\section{Materials and Methods}

Fresh skim milk, dried jamun seeds (Syzygium cumini) and splitted yellow peas were procured from local market of Varanasi. Household dahi inoculums were used as a culture. Dried jamun seeds were grounded into a coarse powder. The packaging material used for packaging of the dahi was polypropylene cups that were covered on top with cellophane.

\section{Preparation of jamun seed extract}

25 grams of jamun seed powder was mixed with $100 \mathrm{ml}$ of ethanol and ultrasonicated for $40 \mathrm{sec}$ at $20 \mathrm{KHz}$ using a probe sonicator. It was then subjected to shaking for 3 hours and then filtered using Whatman paper no.1. The filtered extract was then concentrated using a vacuum rotary evaporator at $50 \mathrm{C}$ and stored at 4-5 C for further use (Pandhi and Poonia, 2019).

\section{Determination of total phenolic content}

$0.5 \mathrm{ml}$ of diluted extract was added to $2.5 \mathrm{ml}$ of $0.2 \mathrm{~N}$ Folin-Ciocalteau reagent and placed for 5 minutes. $2 \mathrm{ml}$ of $75 \mathrm{~g} / \mathrm{L}$ of $\mathrm{Na}_{2} \mathrm{CO}_{3}$ was then added. The above solution was then kept for incubation at room temperature for 2 hours. Absorbance was measured at $760 \mathrm{~nm}$ using $1 \mathrm{~cm}$ cuvette UV-1800 spectrometer (Shimadzu, Japan). Gallic acid (0-800mg/L) was used to produce a standard calibration curve. The total phenolic content was expressed in mg of Gallic acid equivalent (GAE)/ml of extract after applying the dilution factor (Stankovic, 2011).

\section{Radical scavenging activity (\% DPPH inhibition)}

$0.5 \mathrm{ml}$ of ethanol extract of jamun seed was taken and to it $2.5 \mathrm{~mL}$ of DPPH solution $(8 \mathrm{mg} / 100 \mathrm{~mL}$ ethanol) was added. A control was set up with $0.5 \mathrm{ml}$ distilled water as blank and left at room temperature for $30 \mathrm{~min}$. The sample was centrifuged at $3000 \mathrm{rpm}$ for $15 \mathrm{~min}$. In cuvette, $0.5 \mathrm{ml}$ of centrifuged solution was taken and to it $1 \mathrm{~mL}$ of ethanol was added. Absorbance was taken at 517 $\mathrm{nm}$ separately for blank and sample using ethanol as a reference (Nishino et al. 2000).

$\%$ DPPH inhibition $=\left(A_{B}-A_{S} / A_{B}\right) \times 100$

Where,

$A_{B}=O D$ for blank $\quad A_{S}=O D$ for sample

Formulation of pea milk based $d a h i$ fortified with jamun seed extract

\section{Preparation of pea milk}

Pea milk was prepared by adopting single stage extraction technique with slight modification (Upadhyay et al. 2011). Pea milk having water to pea ratio of 5:1 was prepared by first adding $1 \mathrm{~kg}$ pre-processed/treated pea with $2 \mathrm{~L}$ water in the grinder for grinding pea for at least $10 \mathrm{~min}$ followed by addition of remaining $3 \mathrm{~L}$ of water. The obtained mixture was allowed to filter through a muslin cloth and the filtrate was allowed to stand for 2 hours for settling of starch. Collect the upper water fraction as pea milk for further use. The settled starch was separated, dried and collected as a by-product.

\section{Preparation of control dahi}

Skim milk was taken, heated to $85^{\circ} \mathrm{C}$ and then cooled to $40^{\circ} \mathrm{C}$. Milk was inoculated with dahi inoculum@2\% and then $100 \mathrm{ml}$ of it was transferred to each cup. The samples were incubated at $40^{\circ} \mathrm{C}$ in incubator till the proper setting of dahi (Rathi et al. 2013).

\section{Preparation of pea milk fortified dahi incorporated with jamun seed extract}

Pea milk fortified dahi was prepared according to the method given by Rathi et al. (2013) with slight modification (Figure 1). Pea milk of ratio 5:1 was combined with skim milk in the ratio $3: 2$ ( 3 parts of pea milk and 2 parts of skim milk) and total solids of pea milk mixture was adjusted to $16 \%$ by using (4\%) skim milk powder, heated to $85 \mathrm{U} C$ and then cooled to $40^{\circ} \mathrm{C} .1 .5 \%$ of 10 times diluted extract was added and then pea extract combined milk was inoculated with householddahi@2\% and then $100 \mathrm{ml}$ of it was transferred to polystyrene cups. The samples were 


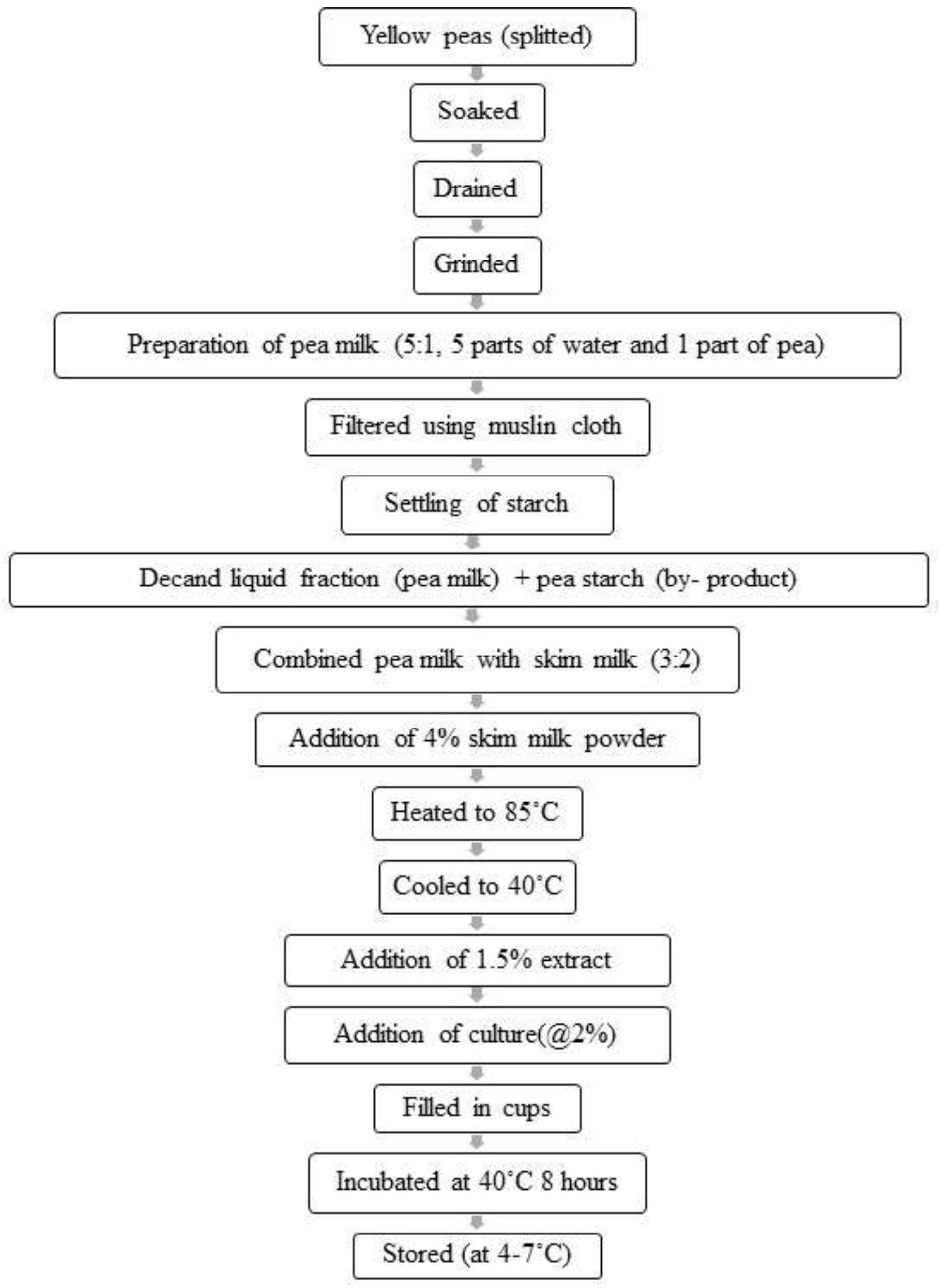

Fig. 1 Flow diagram for preparation of pea milk fortified dahi incorporated with jamun seed extract (JSE)

incubated at $40^{\circ} \mathrm{C}$ in an incubator till the setting of $d a h i$ (Figure 2).

\section{Physicochemical analysis}

Different physicochemical parameters such as \% fat, \% Titratable acidity, \% Protein, $\%$ ash content, viscosity and $\mathrm{pH}$ were determined as per the methods described by Rangana (2001). 


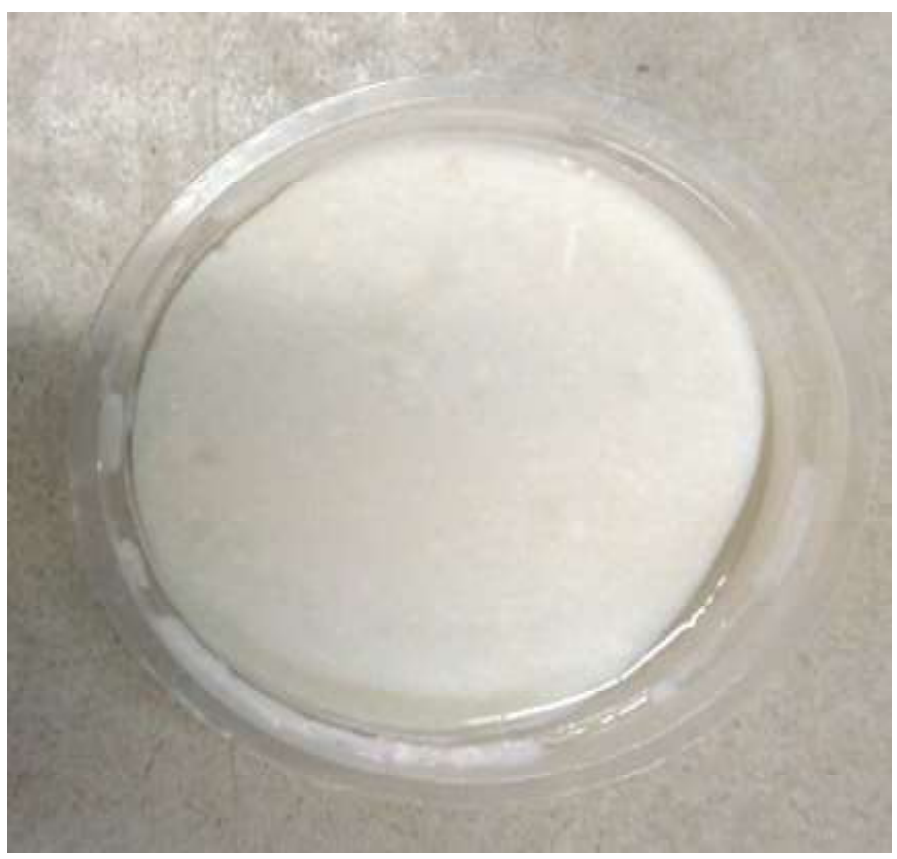

Fig. 2 Pea milk fortified dahi incorporated with jamun seed extract

\section{Color measurement}

L-a-b values for dahi were determined using a Hunter color system, ColorFlex EZ model which was first calibrated using a white tile and black tile. It measures color using a three-dimensional scales, such as CIE L*a*b*, have been developed to objectively quantify color values. This scale defines color as follows: $\mathrm{L}^{*}$ (lightness) axis: black to white (0 to 100) a* (red green) axis: positive values are red; negative values are green; 0 is neutral $b^{*}$ (yellow - blue) axis: positive values are yellow; negative values are blue; 0 is neutral. All visible colors can be quantified within this $3-\mathrm{D}$ rectangular space.

\section{Determination of flavonoid content}

10 grams of dahi sample was repeatedly extracted with $100 \mathrm{ml}$ of $80 \%$ aqueous methanol at room temperature. The mixture was then filtered through a filter paper into a pre-weighed $250 \mathrm{ml}$ beaker (Adham, 2015). The filtrate was transferred into a water bath and allowed to evaporate to dryness and weighed. The percentage flavonoid was calculated as:

$$
\% \text { Total Flavonoids }=\frac{\text { Weight of residue }(g)}{\text { Weight of sample taken }(g)} \times 100
$$

\section{Water holding capacity (WHC) and syneresis}

20 grams of $d a h i$ sample was taken in a $50 \mathrm{~mL}$ centrifuge tube and centrifuged at $2000 \mathrm{rpm}$ for 10 minutes. The weight of clear whey

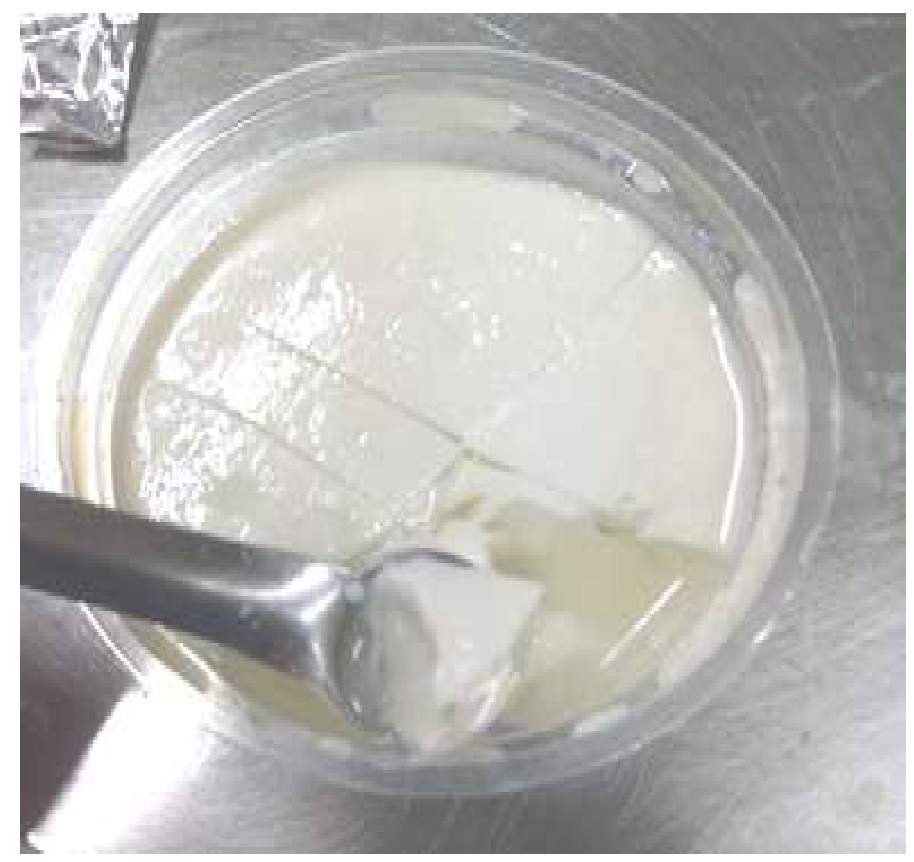

Fig. 3 Showing syneresis in pea milk fortified dahi incorporated with jamun seed extract

separated was measured and the water holding capacity (WHC) was calculated using the formula (Remeuf et al. 2003):

$$
\% W H C=\frac{N D-W D}{N D} \times 100
$$

Where, $\mathrm{ND}=$ weight $d a h i \mathrm{WE}=$ weight of expelled whey.

For syneresis, dahi in the container (100 g) was cleanly cut crosswise with a spatula and around the edge with a thin spatula. A stainless steel wire grid $\left(8 \mathrm{mash} / \mathrm{cm}^{2}\right)$ slightly smaller than the inside diameter of the container, was placed gently on the surface of dahi. At $30 \mathrm{~min}$ interval, the volume of whey obtained was poured off into a $10 \mathrm{ml}$ measuring cylinder, keeping wire grid in place with the help of a spatula, to prevent the dahi from falling out and volume of whey was noted (Marshall, 1982) (Figure 3).

\section{Texture analysis}

Textural parameters were analyzed using Texture Analyzer (TA.XTplus texture profile analyzer, Stable Micro System Ltd, Model TA-XT plus, UK) was calibrated using a $50 \mathrm{~kg}$ weight and the outlined in data acquisition software (Exponent Lite XT PLUS, Ver.4.0.13.0 lite). Back Extrusion Cell (A/BE) with $35 \mathrm{~mm}$ disc and extension bar using $5 \mathrm{~kg}$ load cell was used. Tests were carried out in standard size back extrusion container (50 $\mathrm{mm}$ diameter) with a test speed of $1.00 \mathrm{~mm} / \mathrm{sec}$ and return speed of $5.00 \mathrm{~mm} /$ $\mathrm{sec}$. Trigger force was taken to be $5 \mathrm{~g}$ with $80 \mathrm{~mm}$ return distance and $30 \mathrm{~mm}$ distance. Tests were carried out either in a standard size back extrusion container (50 mm diameter) approx. $75 \%$ full 
or in the original container immediately after the removal from storage. The extrusion disc should be positioned over the sample container. For comparison of cohesiveness and "work of cohesion", the probe must return to the same position above the samples after each test. To do this, it is necessary to calibrate the probe to a distance that is a starting distance, e.g. $30 \mathrm{~mm}$ above the top of the container of the sample surface. When the probe is returning to the start (i.e. pulling out of the sample), it is recommended that the container is held to prevent it from lifting. Four factors that were analyzed are cohesiveness (g), consistency ( $\mathrm{g} \mathrm{sec}$ ), Index of viscosity ( $\mathrm{g} \mathrm{sec}$ ), firmness (g).

\section{Sensory analysis}

The sensory analysis was carried out using a 9- point hedonic scale by serving experimental sample and control sample to a panel of 11-judges from the Department of Dairy Science and Technology, Institute of Agricultural Sciences, Banaras Hindu University, Varanasi, India. The sensory parameters that were studied include color, body and texture, flavor, acidity and overall acceptability. The 9-point hedonic rating scale was arranged such that: Like extremely-9, Like very much-8, Like moderately-7, Like slightly-6, Neither like nor dislike-5, Dislike slightly-4, Dislike moderately-3, Dislike very much-2, Dislike extremely-1 (Amerine et al. 1965). The scores rated by the panel of judges were then statistically analyzed. The samples were code numbered to avoid identification and bias.

\section{Statistical analysis}

The data obtained for various physicochemical, textural and sensory parameters in the present study were analyzed for the significant difference in the treatments by subjecting to the analysis of variance (ANOVA) technique (one way) using Minitab 17 software.

\section{Storage study}

The dahi samples were stored at refrigeration temperature (4 $7^{\circ} \mathrm{C}$ ) and were drawn at 3 days interval up to 21 days. The samples were analyzed for change in $\mathrm{pH}, \% \mathrm{TA}$, sensory evaluation scores, Total phenolic content and \% DPPH during storage using the same method indicated above with $0.5 \mathrm{ml}$ of dahi sample. Also, the estimation of the shelf life of the product was determined until it retains all its sensory, nutritional properties. Stability of jamun seed extract in the product during storage can be determined by analyzing the total phenolic content, DPPH inhibition at different time intervals during storage. The microbiological analysis of the developed value-added dahi product was carried out as per the standard method for coliforms, yeast and molds using the violet red bile agar (VRBA) or potato dextrose agar (PDA), respectively (Kumbhar et al. 2009). $1 \mathrm{~g}$ of the sample was diluted in $9 \mathrm{ml}$ of buffer blanks and subsequent dilutions were prepared up to 10 dilutions.

The number of microbial counts was calculated using the following formula:

No. of Microorganisms $/ g=\frac{\text { No. of colonies } \times \text { dilution factor }}{\text { Weight of aliquot taken }(\mathrm{ml})}$

\section{Cost estimation}

The cost economics of the developed dahi was estimated by taking into account the cost of raw materials, processing cost and labor cost, i.e, fixed and variable cost.

Table 1 Moisture content and total solids content of pea extract

\begin{tabular}{llc}
\hline & \% Total solids & \% Moisture content \\
\hline Pea extract & $5.14 \pm 0.5$ & $94.86 \pm 0.5$ \\
Pea extract + skim milk & $9.42 \pm 1.4$ & $90.58 \pm 1.4$ \\
Pea extract + skim milk + 4\% SMP & $15.94 \pm 2.0$ & $84.06 \pm 2.0$ \\
\hline
\end{tabular}

Values are mean \pm standard deviation, $n=3$

Table 2 Physicochemical parameters for pea milk fortified dahi incorporated with jamun seed extract

\begin{tabular}{llc}
\hline Parameters & Control dahi & Pea $d a h i$ \\
\hline \% Total solids & $15.55 \pm 2.4$ & $15.9 \pm 3.2$ \\
\% Fat & $0.1 \pm 0.00$ & $0.1 \pm 0.00$ \\
\% Protein & $5.4 \pm 0.11$ & $5.8 \pm 0.18$ \\
\% Ash & $1.09 \pm 0.02$ & $0.76 \pm 0.08$ \\
pH & $4.41 \pm 0.04$ & $4.50 \pm 0.8$ \\
Viscosity(cP) & $42 \pm 0.20$ & $38 \pm 0.20$ \\
$\%$ Titratable acidity & $0.80 \pm 0.10$ & $0.82 \pm 0.02$ \\
\hline
\end{tabular}

Values are mean \pm standard deviation, $n=3$ 


\section{Results and discussion}

Total phenolic content \& antioxidant activity (\% DPPH inhibition) of extract

Using the standard curve, the total phenolic content of the extract was determined and was found to be $425.90 \pm 15.2 \mathrm{mg}$ of gallic acid equivalent $/ \mathrm{mL}$ of extract. The results indicate the presence of higher total phenols with high yield of $12.76 \pm 1.45 \%$. UAE (Ultrasonicated assisted extraction) was considered to be more effective than other conventional extraction because of its high efficiency and efficacy in the extraction of various bioactive constituents from the inactive solid matrix without any detrimental effects (Cho et al. 2006). The total antioxidant activity of the ethanolic extract was found to be $95.83 \pm 0.50 \%$. The ultrasonication process involves collapse of bubbles that cause physical, chemical or mechanical disruption of the biological membrane of the extractable compound and hence, provides better efficiency and efficacy (Cares et al. 2009; Metherel et al. 2009). Higher phenolic content usually conveys higher antioxidant activity (Margaret et al. 2015).

\section{Formulation of pea milk}

Pea milk formulated with water to pea ratio of 5:1 (optimized ratio) was subjected to determination of moisture content and total solid content and results are indicated in Table 1. Skim milk powder (a) $4 \%$ was added to pea milk fortified milk to adjust total solid content to $16 \%$ as this percent of total solid is required for desirable body and texture of dahi (Chowdhury and Bhattacharyya, 2014).

\section{Physicochemical analysis}

Various physicochemical parameters of formulated dahi were determined and the results are tabulated in Table 2.

\section{Texture analysis (TA)}

The average values for the four texture parameters such as consistency, cohesiveness, index of viscosity, firmness were found to be $5419.2 \pm 45.1,86.16 \pm 3.56,176.56 \pm 2.99,219.055 \pm$ 4.34 respectively. The values of consistency and firmness of dahi sample were found to be lower than that of control with consistency and firmness of 6252.1 \pm 42.6 and $325.025 \pm 3.31$ respectively. This is in accordance with the study conducted by

Table 3 Sensory evaluation of developed product

\begin{tabular}{lll}
\hline Parameter & Sample & Control \\
\hline Color & $7.9 \pm 0.9$ & $8.7 \pm 0.7$ \\
Flavor & $7.6 \pm 1.2$ & $8.9 \pm 0.6$ \\
Body and texture & $8.3 \pm 0.7$ & $8.4 \pm 0.3$ \\
Consistency & $8.6 \pm 0.7$ & $8.5 \pm 0.6$ \\
Acidity & $7.1 \pm 0.6$ & $7.8 \pm 0.2$ \\
\hline
\end{tabular}

Values are mean \pm standard deviation, $n=11$
Sivakumar and Dhanalakshmi (2015) who also observed reduction in firmness and consistency of dahi on addition of plant extract. They suggested that plant extract might have showed inhibitory action on starter culture, thus delaying the curd formation process and affecting the overall texture of the final product.

\section{Water holding capacity (WHC) and syneresis}

Water holding capacity of dahi relates to the ability of its constituents to hold water within dahi matrix. The \% water holding capacity of the formulated dahi was found to be $60.35 \pm 1.34$. There was a significant difference $(\mathrm{p}<0.05)$ between the water holding capacity of a control sample of dahi which was $70.23 \pm 1.56$, the reason may be higher ability of milk protein to hold more water as compared to pea protein in combination with milk proteins (Table 3). Syneresis is the separation of whey from the curd and expressed as $\mathrm{ml}$ as depending on the method followed. The extent of syneresis is indicative of the quality of dahi. Consumers prefer dahi with no visible whey separation. Presence of separated whey indicates excessive fermentation and stored dahi, lacking consumer acceptance in the market. Syneresis for formulated dahi was found to be $8.2 \pm 0.4 \mathrm{ml} / 100 \mathrm{~g}$ whereas, for control sample, it was found to be $7.8 \pm 0.4 \mathrm{ml} / 100 \mathrm{~g}$ which was lower than the formulated product, this could be due to the comparatively lower water holding capacity of the formulated product due to variation in the composition. As per the findings, the addition of plant extract containing polyphenols appears to encourage the contraction of protein matrix and aids the dismissal of whey, decreasing the amount of entrapped water in protein matrix (Masmoudi et al. 2020). The difference in the acidity could also be a major contributor of disruption of protein network (Ranadheera et al. 2012),

\section{Color estimation}

The L-a-b values for the formulated product was found to be $\mathrm{L}=$ $83.85 \pm 0.42, \mathrm{a}=0.37 \pm 0.01, \mathrm{~b}=14.21 \pm 0.02$. The L- value was more on the higher side indicating the lightness of the product. Low + a value indicate a tinch of red color in the product, $+b$ indicates the color of the products to be towards yellow. The overall color of the product can be expressed as light yellow with a very light tint of red color. Addition of plant extract slightly lowers down the lightness of the product and results in slight shift toward darker side (Shokery et al. 2017).

\section{Sensory analysis}

The data obtained by sensory evaluation in the present study reveals that there was no significant difference between the consistency and body and texture of developed dahi and the control dahi the reason for this could be the similar level of $\%$ total solids in both which was the major contributor towards the body and texture. Color, flavour and acidity of the dahi were found to be significantly affected by the incorporation of extract 
Table 4 Effect of storage period on the shelf life of dahi for 21days

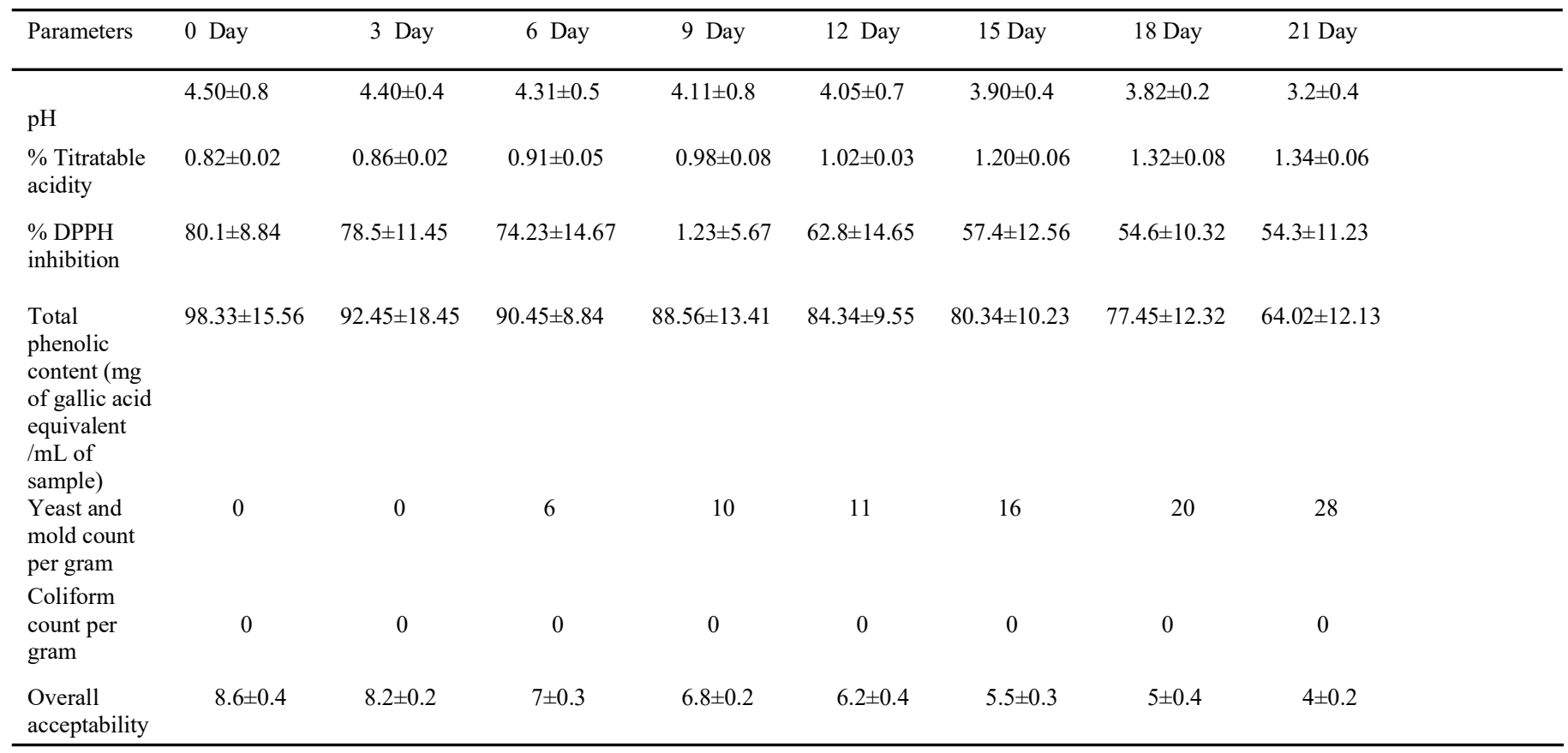

Values are mean \pm standard deviation, $n=3$

Table 5 Cost estimation of the developed product

\begin{tabular}{llc}
\hline Ingredient & Amount/ 100g cup & Cost (Rs.) \\
\hline Yellow peas & $12 \mathrm{~g}$ & 0.6 \\
Jamun seed extract & $1.5 \mathrm{ml}$ & 1.5 \\
Skimmilk & $40 \mathrm{ml}$ & 2.8 \\
Skim milk powder & $4 \mathrm{~g}$ & 1.33 \\
Packaging cost & $1 \mathrm{cup}+$ aluminium foil & 1.0 \\
Inoculum & $1.5 \mathrm{~g}$ & 0.165 \\
& Total & 7.39 \\
Processing cost & Per cup & 1.0 \\
& Total & 8.39 \\
Marketing and distribution expenses @ $25 \%$ of product & Per cup & 2.097 \\
& Total & 10.48 \\
Profit margin @ $30 \%$ of cost of product & Per cup & 2.517 \\
& Total cost (per $100 \mathrm{~g}$ cup) & 13 Rs. \\
\hline
\end{tabular}

and fortification of pea milk in the dahi. The sensory score for flavour of developed dahi was lower as compared to the control, the reason for this could be the beany flavour that might have affected the score. The incorporation of extract and pea milk has contributed towards a yellowish color of the developed product that may have resulted in the lower sensory score for color parameter in the developed product. Further, the difference in the score for acidity might also be attributed by the incorporation of extract and pea milk in the product (Table 3). Addition of any herbal extract into a product or modification of its composition could be the sole reason for the lowered sensory scores by panellists (Bajalanlou and Pakbin, 2016)

\section{Storage study}

Storage study of formulated dahi was conducted with samples which were seal packed in polyethylene bags and were store at $4-5^{\circ} \mathrm{C}$ during the whole storage period. The parameters that were studied during the storage study were $\mathrm{pH}, \%$ titratable acidity (\%TA), \% DPPH inhibition, total phenolic content and overall acceptability. During storage of dahi sample $\mathrm{pH}$ had shown a decreasing trend in value whereas an increasing trend was observed in \% TA. The justification for the observed trend was increased lactic acid concentration that simultaneously decreases the $\mathrm{pH}$ of dahi. The functional constituents such as phenols had shown a gradual decrease in concentration relating to loss of 
phenols during storage. Loss of phenols during storage affect the antioxidant property hence a decreasing pattern was observed for \% DPPH inhibition. From microbiological analysis, it was found that the coliform count of dahi was nil throughout the storage period. Yeast and mold count was also found to be less than the standard value of $100 / \mathrm{g}$ (Table 4). Considering all these parameters, the extent to which these parameters ensure safety and quality of product was chosen to be the estimated shelf life. A shelf life of 12 days was estimated for the product, taking into account the maximum possible concentration of phenols with almost all other quality and safety aspects were maintained. Yadav et al. (2007) evaluated low-fat probiotic dahi prepared with Lactococci starters and 2 adjunct probiotic cultures of Lactobacillus acidophilus and Lactobacillus casei under refrigerated storage at $7^{\circ} \mathrm{C}$ and found that dahi stored for 8 days may be acceptable to consumers. Parseeda and Nanu (2007) investigated changes in quality of curd stored under refrigeration $\left(4-11^{\circ} \mathrm{C}\right)$ for a period of 21 days with respect to acidity, $\mathrm{pH}$, and sensory parameters. The results indicated that the product had a shelf life of 9 days under refrigerated storage (Table 4).

\section{Cost estimation}

The estimated cost of the developed product was found to be Rs. 13 per $100 \mathrm{~g}$ cup which is quite comparable to the commercial dahi product available in the market which generally cost Rs 20 or 22 per $200 \mathrm{~g}$ of cup (Table 5). Hence, from the economy point of view the product was quite feasible.

\section{Conclusion}

Pea milk fortified dahi incorporated with jamun seed extract was successfully developed with an estimated shelf life of 12 days under refrigerated storage. The formulated product was developed in view of the increasing demand for products supplemented with plant based nutrients and phytonutrients. The developed product might be suitable for diabetic people as it contains phytonutrients extracted from jamun seeds and had shown higher antioxidant activity and total phenolic content. The developed product was found to be good in terms of body and texture but has a slightly lower liking for sensory parameters such as flavor and color. The estimated cost of the product was also comparable to the market dahi. Further, the pea starch collected as a byproduct of pea milk can be dried and can be put forward for further useful applications such as a food thickener or as a base material for development of starch based edible film for food packaging.

\section{References}

Adham AN (2015) Comparative extraction methods, phytochemical constituents, fluorescence analysis and HPLC validation of rosmarinic acid content in Mentha piperita, Mentha longifolia and Osimum basilicum. J Pharmacogn Phytochem 3: 130-139
Amerine MA, Pangborn RM, Roessler EB (1965) Principles of sensory evaluation of foods. Academic Press, London.

Bajalanlou F, Pakbin B (2016) Chemical properties and sensory evaluation of probiotic yoghurt manufactured with aqueous extract of aloevera. $\mathrm{J}$ Biol Today's World 5: 197-202

Baliga MS, Bhat HP, Baliga BRV, Wilson R, Palatty PL (2011) Phytochemistry, traditional uses and pharmacology of Eugenia jambolana Lam.(black plum): a review. Food Res Int 44: 17761789

Cares MG, Vargas Y, Gaete L, Sainz J, Alarcon J (2009) Ultrasonically assisted extraction of bioactive principles from Quillaja Saponaria Molina. Physics Procedia 3: 169-178

Cho YJ, Hong JY, Chun HS, Lee SK, Min HY (2006) Ultrasonication assisted extraction of resveratrol from grapes. J Food Eng 77: 725730

Chowdhury SR, Bhattacharyya AK (2014) Production, characterization and value addition of dahi made from raw, pasteurized and double pasteurized milk. Int J Res Eng Technol 3: 602-607

Denkova Z, Yanakieva V, Denkova R, Dobrev I, Kozludzhova S (2013) Examining the possibilities for application of pea milk in obtaining

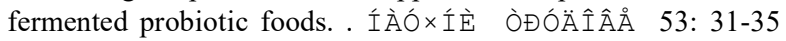

Desai GB, Kshirsagar RB, Sawate AR (2019) Effect of jamun (Syzygium cumini) seed powder extract on physico-chemical and organoleptic properties of beverage. The Pharma Innovation J 8: 1003-1010

FAOSTAT (2011) Food and Agriculture Organization Statistics. Food security data and definitions 2005-2007.

Fazilah NF, Ariff AB, Khayat ME, Rios-Solis L, Halim M (2018) Influence of probiotics, prebiotics, synbiotics and bioactive phytochemicals on the formulation of functional yogurt. J Functional Foods 48: 387-399

Kumbhar SB, Ghosh JS, Samudre SP (2009) Microbiological analysis of pathogenic organisms in indigenous fermented milk products. Adv $\mathrm{J}$ Food Sci Technol 1: 35-38

Margaret E, Shailaja AM, Venugopal Rao (2015) Evaluation of antioxidant activity in different parts of Syzygium cumini (Linn.). Int J Curr Microbiol Appl Sci 4: 372-379

Marshall RJ (1982) An improved method for measurement of syneresis of curd formed by rennet action on milk. J Dairy Res 49: 329-336

Masmoudi M, Ammar I, Ghribi H, Attia H (2020) Physicochemical, radical scavenging activity and sensory properties of a soft cheese fortified with Arbutus unedo L. extract. Food Biosci 35: 1-8

Metherel AH, Taha AY, Izadi H, Stark KD (2009) The application of ultrasound energy to increase lipid extraction throughput of solid matrix samples [flaxseed]. Prostaglandins, Leukotrienes and Essential Fatty Acids 81: 417-23

Naczk M, Shahidi F (2006) Phenolics in cereals, fruits and vegetables: Occurrence, extraction and analysis. J Pharm Biomed Anal 41:15231542

Nishino T, Shibahara-Sone H, Kikuchi-Hayakawa H, Lshikawa F (2000) Transit of radical scavenging activity of milk products prepared by Millard reaction and Lactobacillus caseii strain shirota fermentation through the hamster intestine. J Dairy Sci 83: 915-922

Pandhi S, Poonia A (2019) Phytochemical screening of jamun seeds using different extraction methods. Pharma Innovation J 8: 226-231

Parihar AK, Bohra A, Dixit GP (2016) Nutritional benefits of winter pulses with special emphasis on peas and rajmash. Biofortification Food Crops 8: 22-34

Parseeda R, Nanu E (2007) Keeping quality of curd under refrigeration. J Food Sci Technol 44: 400-403

Ranadheera CS, Evans C, Adams M, Baines S (2012) Probiotic viability and physico-chemical and sensory properties of plain and stirred fruit yogurts made from goat's milk. Food Chem 135: 1411-1418 
Ranganna S (2001) Handbook of analysis of fruits and vegetable products. $2^{\text {nd }}$ ed., Tata Mc-Graw-Hill Pub. Com. Ltd., New Delhi.

Rathi M, Upadhyay N, Dabur RS, G Ankit (2013) Formulation and physicochemical analysis of whey-soymilk dahi. J Food Sci Technol 52: 968-975

Remeuf F, Mohammed S, Sodini, Tissier JP (2003) Preliminary observation on the effects of milk fortification and heating on microstructure and physical properties of stirred yoghurt. Int Dairy J 13: 773-782

Sandhya S, Khamrui K, Prasad W, Kumar MCT (2018) Preparation of pomegranate peel extract powder and evaluation of its effect on functional properties and shelf life of curd. LWT- Food Sci Technol 92: 416-421

Shokery ES, El-Ziney MG, Yossef AH, Mashaly RI (2017) Effect of green tea and Moringa leave extracts fortification on the physicochemical, rheological, sensory and antioxidant properties of set-type yoghurt. J Adv Dairy Res 5: 2

Sivakumar GM, Dhanalakshmi B (2015) Physico-chemical and organoleptic evaluation of dahi prepared with betel leaf extract. Shanlax Int J Arts, Sci Humanities 3: 134-137
Stankovic MS (2011) Total phenolic content, flavonoid concentration and antioxidant activity of Marrubium peregrinum L. extracts. Kragujevac J Sci 33: 63-72

Upadhyay N, Dabur RS, Rathi M (2011). Development and shelf life study of flavoured whey-soya milk beverage. Indian J Dairy Sci 64: 92101

Yadav H, Jain S, Sinha RP (2007) Evaluation of changes during storage of probiotic dahi at $7{ }^{\circ} \mathrm{C}$. Int J Dairy Technol 60: 205-210

Yadav K, Bajaj RK, Mandal S, Saha P, Mann B (2018) Evaluation of total phenol content and antioxidant properties of encapsulated grape seed extract in yoghurt. Int J Dairy Technol 71: 96-104

Zimmer AR, Leonardi B, Miron D, Schapoval E, Oliveira JR, Gosmann G (2012) Antioxidant and anti-inflammatory properties of Capsicum baccatum: from traditional suse to scientific approach. J Ethnopharmacol 139: 233 